DOI: $10.14746 / \mathrm{amp} .2016 .21 .10$

MARCIN WRZOS

Redaktor naczelny czasopisma „Misyjne Drogi”

\title{
Przeobrażenia w posłudze polskich braci oblatów na misjach w świetle artykułów publikowanych w dwumiesięczniku ,Misyjne Drogi”
}

Zgromadzenie Misjonarzy Oblatów Maryi Niepokalanej (OMI) zostało założone 25 stycznia 1816 r. przez późniejszego biskupa Marsylii św. Eugeniusza de Mazenoda, a zatwierdzone w 17 lutego 1826 r. przez papieża Leona XII. Od samego początku w strukturach zgromadzenia obok ojców - księży, kleryków, istnieli bracia zakonni, których głównym zadaniem było wspieranie ojców w ewangelizacji. Zajmowali się pracami fizycznymi, a z czasem także bezpośrednią ewangelizacją. Pierwszym oblatem polskiego pochodzenia pracującym na misjach był br. Józef Andrzejewski OMI, który z ówczesnej Prowincji Niemieckiej wyjechał na misję na Sri Lankę (Cejlon) w 1920 r. Dziś na misjach pracuje kilku braci z prowincji polskiej: dwóch na Madagaskarze, jeden w Kamerunie i trzech na Ukrainie.

Gdy tylko po długotrwałych negocjacjach z organami Polskiej Rzeczpospolitej Ludowej (PRL) władze prowincji uzyskały zgodę w 1983 r. na druk „Misyjnych Dróg”, jednym z najważniejszych zadań periodyku było informowanie o misjach, ze specjalnym uwzględnieniem oblatów, w tym także braci. Dziś jest to jedno z najważniejszych czasopism misyjnych w Polsce. Jego nakład wynosi 25 tys. egzemplarzy, objętość 72 stron w grzbiecie głównym. Do pisma dołączona jest też szesnastostronicowa wkładka dla dzieci. W Internecie pismo jest czytane przez 2000-2500 osób dziennie i jako jedyne czasopismo misyjne dostępne jest w tzw. wolnej sprzedaży.

Ramami czasowymi niniejszej analizy są: 1983 r. - rozpoczęcie wydawania czasopisma oblackiego i 2015 r. - ostatni rok wydawniczy. Badania prowadzono metodą historycznej analizy prasowej. Podzielono ją na trzy etapy, związane z przeobrażaniem periodyku: 
1. Lata 1983-1994 (kwartalnik dwubarwny, red. Alfons Kupka OMI).

2. Lata 1995-2011 (dwumiesięcznik pełnobarwny, red. Alfons Kupka OMI).

3. Lata 2012-2015 (dwumiesięcznik pełnobarwny dostępny także w internecie, red. Marcin Wrzos OMI).

\section{Lata 1983-1994}

W pierwszym okresie działalności wydawniczej „Misyjnych Dróg” czasopismo ukazywało się jako dwubarwny kwartalnik w nakładzie 10 tys. egzemplarzy, ze względu na to, że redakcja nie otrzymała od władz pozwolenia na większy. W pierwszym roku działalności wydawniczej oblackiego pisma opublikowany został jeden artykuł związany z posługą braci oblatów na misjach. Było to wspomnienie Walentego Zapłaty OMI na temat nieżyjącego br. Stanisława Tomkiewicza OMI z Kamerunu. Na jego przykładzie została przedstawiona posługa braci zakonnych w tym kraju. Zajmowali się oni pracami technicznymi, a szczególnie budową kościołów, kaplic, klasztorów, szkół i ośrodków zdrowia (Zapłata 28-29).

W opracowaniach z drugiego roku wydawniczego Antoni Kurek OMI i Michał Dąbrowski OMI napisali o braciach oblatach pracujących od 1936 r. w Arktyce: Stanisławie Szczepaniaku OMI, Józefie Sobeckim OMI, Józefie Kańtochu OMI, Ignacym Dorabiale OMI, Ludwiku Jurczyku OMI, Michale Dąbrowskim OMI i Jerzym Mrugale OMI. Wykonywali oni zazwyczaj profesje techniczne. Byli mechanikami, budowlańcami, instalatorami sanitarnymi, cieślami i stolarzami, a także piekarzami czy sternikami okrętów misyjnych. W ten sposób wspierali bezpośrednie zaangażowanie misyjne księży oblatów. Antoni Kowalczyk OMI, obecnie sługa Boży, został opisany w artykułach monograficznych Leonarda Głowackiego OMI. Autor zwracał uwagę na jego pracowitość, uzdolnienia mechaniczne połączone z głęboką duchowością, dzięki czemu sprawdzał się jako formator w szkołach katolickich na poziomie średnim. Antoni Kurek OMI zanalizował i przedstawił historię pracy polskich oblatów na Sri Lance, z uwzględnieniem braci: Józefa Andrzejewskiego OMI, Stefana Andrzejewskiego OMI, Leonarda Zyguły OMI, Wincentego Siejki OMI, Stefana Dudy OMI i Stanisława Wyrymy OMI. Byli to pierwsi misjonarze oblaccy, którzy wyjechali z kraju w latach dwudziestych XX w. Zabezpieczali funkcjonowanie kolegiów, ośrodków zdrowia i sierocińców. Ich zadaniem było wspieranie pracy księży misjonarzy $(\mathrm{Ku}-$ rek 1984a, 14-21; Dąbrowski 1984a, 28-36; Głowacki 1984a, 37-39; Dąbrowski 1984b, 44; Kurek 1984b, 20-25; Głowacki 1984b, 54-58; Kurek 1984c, 12-15)․․

${ }^{1} \mathrm{~W}$ tym roku wydawniczym opublikowana została największa liczba artykułów dotycząca oblackich braci zakonnych. 
W tekście z trzeciego rocznika pisma br. Michał Dąbrowski OMI podsumowował wizytę Jana Pawła II, a także swoją działalność misyjną w Kanadzie Północnej. Była ona ukierunkowana na pomoc techniczną i dzielenie życia z Eskimosami, którzy przemieszczali się w Arktyce, budując każdorazowo osady. Bracia pomagali księżom misjonarzom-ewangelizatorom. Inny autor - Alfons Kupka OMI przeprowadził rozmowę z br. Stanisławem Wyrymą OMI, ostatnim polskim oblatem pracującym na Sri Lance. Akcentował on swoją pracę techniczną związaną z budową i prowadzeniem rozgłośni radiowej czy elektryfikacją misji. Przedstawił powołanie brata jako tego, który też jest zaangażowany w bezpośrednią ewangelizację przez prowadzenie i formację grup młodzieżowych. Zauważył rolę świadectwa życia brata zakonnego jako przekonującego narzędzia ewangelizacyjnego (Dąbrowski 1985, 23; Kupka 1985, 26-30).

$\mathrm{W}$ artykułach z roku 1986 nie było istotnej wzmianki dotyczącej prac realizowanych przez polskich braci oblatów na misjach. Wiązało się to m.in. ze zmianą koncepcji pisma. Do tej pory przedstawiano w nim poszczególne misje oblackie, dlatego opracowania dotyczące braci znajdowały się na łamach „Misyjnych Dróg”. Od tego roku wydawniczego główną oś tematyczną periodyku stanowiły misyjne pielgrzymki papieskie. Publikowano także prezentacje Kościołów miejscowych, do których przybywał biskup Rzymu. W związku z tą zmianą mniej tekstów dotyczyło posługi oblatów. W 1987 r. br. Michał Dąbrowski OMI opisał wizytę prymasa Józefa Glempa w Kanadzie i jego zainteresowanie pracami wykonywanymi w tym kraju przez polskich braci oblatów, a szczególnie Antoniego Kowalczyka OMI (Dąbrowski 1987, 36-37). Rok później nie ukazał się na łamach pisma żaden tekst dotyczący braci oblatów na misjach.

Śmierć br. Stanisława Wyrymy OMI, ostatniego polskiego oblata na Sri Lance, zdominowała kolejny rocznik wydawniczy pisma. Brat Stanisław pracował ponad 60 lat na misjach w tym państwie. Najpierw zajmował się pracami ślusarskimi i elektrycznymi w szkołach prowadzonych przez zgromadzenie. Od 1933 r., w związku z brakiem odpowiednich techników na miejscu, obsługiwał technicznie radio państwowe. Duszpastersko był zaangażowany w formację laikatu młodzieżowego na wyspie. Autorzy artykułów charakteryzowali jego pracę jako żarliwą. Szczególnie akcentowano jego umiłowanie ubóstwa i świadectwo życia chrześcijańskiego (Alfons Kupka OMI, Anzelm Silva OMI i Bernard Quintus OMI). Kolejnym zagadnieniem poruszanym w kontekście posługi braci zakonnych były misje wśród Eskimosów (Inuitów) i postać br. Michała Dąbrowskiego OMI. Jego praca polegała na prowadzeniu statków misyjnych i zajmowaniu się psimi zaprzęgami. W ten sposób zapewniał transport księży - misjonarzy na tych terenach. Był też budowniczym, krawcem, elektrykiem - wykonywał prace, które były potrzebne na misji. Lubił dzielić życie z Eskimosami. Razem z nimi przemieszczał się, polując i łowiąc, by 
w ten sposób przekonać ich do działalności Kościoła. Wieczorami wykorzystywał czas do ich ewangelizacji i prowadzenia modlitwy w igloo (Waldemar Puchała OMI, Jan Sajewicz OMI). W przypadku braku księży misjonarzy, którzy sporadycznie docierali do przemieszczających się osad, zastępował ich w bezpośredniej działalności ewangelizacyjnej (Kupka 1989, 51; Puchała 38; Silva i Quintus 51; Sajewicz 52-54).

W kolejnym roku na łamach pisma nie wspominano o braciach misjonarzach. W 1991 r. z okazji jubileuszu 150-lecia pracy oblatów w Kanadzie Jarosław Różański OMI pisał o wspieraniu przez nich księży misjonarzy w Kanadzie Północnej. Posługa misyjna braci na tych ternach polega przede wszystkim na pracach związanych $\mathrm{z}$ zabezpieczeniem technicznym pracy księży misjonarzy. Bracia pracują jako mechanicy, hydraulicy, drwale, marynarze, drukarze, pielęgniarze. Mniej istotne jest bezpośrednie ich zaangażowanie w ewangelizację; można je określić jako dodatek do wykonywanych przez nich prac technicznych. To zaangażowanie nie zawsze jest wspierane przez przełożonych (Różański 18-19). W kolejnym roku nie opublikowano zwartych tekstów dotyczących braci oblatów na misjach.

Bracia Grzegorz Rosa OMI i Zygmunt Wolnik OMI dalią świadectwa swojej pracy misyjnej w Kamerunie i na Madagaskarze. Pierwszy opisał swoją działalność budowlaną, gdyż zajmuje się pracami związanymi z powstawaniem kościołów, kaplic i klasztorów. Drugi prowadził pomoc humanitarną wśród ofiar kolejnego cyklonu na Madagaskarze. Na co dzień trudni się edukacją rolniczą miejscowych, prowadząc pokazową farmę (Rosa 1993, 39; Wolnik 1993, 39).

W kolejnym roczniku periodyku o pracy misyjnej na Madagaskarze pisali bracia Zygmunt Wolnik OMI i Grzegorz Guzik OMI. Pierwszy przedstawił pracę humanitarną oblatów po kolejnym cyklonie na Czerwonej Wyspie, o czym wspominał w poprzednim roczniku pisma, natomiast drugi o posłudze i pracy formacyjnej $\mathrm{w}$ seminarium duchownym. Zauważalna jest zmiana pracy z technicznej, dotyczącej jedynie samych misji, na rzecz pomocy socjalnej dla ludzi, którymi zajmują się bracia oblaci. Mariusz Lorenc OMI przedstawił relację ze swojej pracy związanej z budową kościoła w Garigombo-Ngoundi w Kamerunie. Jednocześnie zwrócił uwagę na konieczność zaangażowania braci w budowanie miejscowego Kościoła (Wolnik 1994, 35-36; Lorenc 1994, 36-37; Guzik 1994, 37-38).

\section{Lata 1995-2011}

Kolejny etap wydawania „Misyjnych Dróg” wiąże się z dużymi zmianami w szacie graficznej oraz objętości i nakładzie pisma. Periodyk do tej pory wydawany w technice dwubarwnej otrzymał pełny kolor. Zwiększona została 
częstotliwość wydawania do sześciu numerów rocznie. Nakład pisma uzyskał w tym okresie najwyższy poziom - 30 tys. egz., a w redagowanie periodyku zostały włączone osoby świeckie.

Brat Daniel Kloch OMI w 1995 r. napisał o pracy na Madagaskarze. Jego najważniejszym zajęciem były sprawy gospodarcze i techniczne misji. Starał się prowadzić miejscowe wspólnoty chrześcijańskie, szczególnie te, które nie miały stałego dostępu do księży misjonarzy. Wyszedł z inicjatywą założenia na Madagaskarze pokazowej farmy, aby nauczyć miejscową ludność wydajniejszego rolnictwa (Kloch 1995, 31).

W kolejnym roczniku pisma prace budowlane, tym razem na południu Kamerunu, wśród Pigmejów, przedstawił br. Grzegorz Rosa OMI. W swoich analizach zwrócił uwagę na miejscowe wierzenia i przywiązanie ludzi do klątw. Przedstawił działania miejscowych czarowników (Rosa 1996, 27).

Brat Mariusz Lorenc OMI złożył misjograficzne relacje z codziennej pracy w Kamerunie na łamach „Misyjnych Dróg”. Opisał pracę w buszu wśród robotników leśnych, którzy pracują przy wyrębie, a także swoją pracę duszpasterską wśród nich: wieczorne rozmowy, prowadzenie modlitw, głoszenie katechez. Przedstawił pierwszą przeprowadzoną przez siebie budowę kaplicy. Drugim tematem podjętym w tym wydaniu, tym razem przez Nicolę Ferrerę OMI, było przypomnienie czytelnikom pisma postaci sługi Bożego br. Antoniego Kowalczyka OMI, w 50. rocznicę jego śmierci. Wskazywał na jego pracowitość, długie godziny spędzone w warsztacie, a także pogłębioną duchowość. Według autora był to najważniejszy rodzaj formacji, jaką uzyskali uczniowie szkoły katolickiej, w której pracował. Przedstawił także aktualny stan prac nad jego beatyfikacją (Lorenc 1997a, 26-27; Ferrara, 13-15; Lorenc 1997b, 30).

Pracę w prenowicjacie na Madagaskarze opisał w 1998 r. br. Daniel Kloch OMI. Wskazał na ważne elementy posługi brata: pracę fizyczną (w tym wypadku wykończenie budynków, szczególnie prace stolarskie i elektryczne) oraz pomoc $\mathrm{w}$ formacji prenowicjuszy. Jednym $\mathrm{z}$ elementów posługi brata jest modlitwa, która wskazuje formowanym na jego zażyłość z Bogiem (Kloch 1998, 26).

Przez kolejne dwa lata na łamach pisma nie opublikowano zwartych artykułów dotyczących posługi braci oblatów na misjach.

Wprowadzanie nabożeństw różańca i koronki do Bożego Miłosierdzia na Madagaskarze opisał w kolejnym artykule br. Daniel Kloch OMI. Kontynuował temat edukacji agrarnej wśród autochtonów, a także działalności ewangelizacyjnej we wspólnotach rozsianych w lasach tropikalnych. Natomiast Tadeusz Orzechowski OMI ukazał swoją posługę w Kamerunie Północnym. Przedstawił rodzaje swojego zaangażowania: naprawy aut, budowy i remonty klasztorów oraz domów mieszkalnych. Pisał o losach dzieci ulicy i metodach 
zwalczania problemu sieroctwa społecznego (Kloch 2001, 28; Orzechowski 2001, 50).

W kolejnym roczniku pisma br. Grzegorz Rosa OMI, misjonarz z Kamerunu, zaprezentował swoje doświadczenie długotrwałej choroby i leczenia w Polsce. Przedstawił prowadzone przez siebie prace budowlane w nowicjacie sióstr służebniczek w Ngaoundéré, które traktuje jako wypełnienie powołania zakonnego (Rosa 2002, 50).

W następnym roku nie zamieszczono materiałów dotyczących braci zakonnych na misjach.

W roczniku 2004 nie publikowano wypowiedzi braci oblatów z Polski. Znalazło się natomiast opracowanie Shivanthy Waasa OMI dotyczące posługi braci oblatów z Polski na Sri Lance. Autor podkreślał ich zaangażowanie $\mathrm{w}$ rozwój jednej $\mathrm{z}$ najbardziej prężnych aktualnie prowincji zgromadzenia (Waas 13).

Przez kolejne dwa lata na łamach pisma nie ukazały się opracowania związane $\mathrm{z}$ braćmi na misjach.

W roku 2007 Leonard Głowacki OMI w obszernym opracowaniu kolejny raz opisał postać br. Antoniego Kowalczyka OMI. Szczegółowo ukazał jego dzieciństwo, wyjazd do Niemiec w poszukiwaniu pracy, a także moment wstąpienia do nowicjatu w Holandii. Analizował powołanie brata zakonnego na misjach, które poza modlitwą obejmuje przede wszystkim prace fizyczne, w tym przypadku kowala, hydraulika, mechanika, który pomimo utraty dłoni pracuje w tartaku. Cechą charakterystyczną omawianego brata była głęboka pobożność maryjna i adoracyjna, a także apostolat modlitwy (Głowacki 2007, 34-36).

W kolejnym roku działalność duszpasterską na Madagaskarze opisał br. Daniel Kloch OMI. Omówił on rozszerzający się kult Bożego miłosierdzia we wspólnotach katolickich w buszu, a także w specjalistycznych formach duszpasterstwa w więzieniu i wśród studentów. Ukazaał powołanie brata jako tego, który angażuje się bezpośrednio w ewangelizację misyjną (Kloch 2008, 33).

Podobnie rolę brata zakonnego postrzega Christian Ramisy OMI. W swojej publikacji w roczniku 2009 „Misyjnych Dróg” zauważył komplementarność powołania kapłańskiego i braterskiego na misjach. Realizuje swoje powołanie w pracy na farmie pokazowej dla Malgaszy, jako formator dla kandydatów na braci w zgromadzeniu, a także jako duszpasterz-katecheta na misji (Ramisy i Wrzos 2009, 50).

W kolejnym roku wydawniczym poświęcenie katedry w nowej diecezji w Yokaduoumie w Kamerunie Północnym było okazją dla autorów artykułów do ukazania braterskiego powołania misyjnego. Rolą braci na misjach, w tym przypadku: Jacka Ziomka OMI, Stanisława Jankowicza OMI, Alojzego Chrószcza OMI, jest dbanie o zaplecze materialne, a szczególnie budowę 
kościołów, kaplic i szkół (Chrószcz, 18-21; Ziomek 2010, 28-29; Jankowicz, 34-37).

Zaangażowanie w promocję ludzką, jak i dzielenie życia braci z ludem miejscowym, opisane zostały w opracowaniach Jacka Ziomka OMI w kolejnym roku wydawniczym pisma (Ziomek 2011a, 34-36; Ziomek 2011b, 28-29).

\section{Lata 2012-2015}

W 2012 r. zmieniła się szata graficzna pisma, jego objętość zwiększyła się do 76 stron, pojawiła się wkładka dziecięca. Nowa redakcja pod kierunkiem Marcina Wrzosa OMI położyła dodatkowy nacisk na obecność pisma w przestrzeni cyfrowej. Czasopismo zmieniło formułę z periodyku w dużej mierze ukazującego pracę oblatów na uniwersalną. Związane to było ze zmniejszającą się liczbą misjonarzy oblackich z Polski.

W roczniku 2012 „Misyjnych Dróg” przedstawiona została, w formie świadectwa, posługa misyjna br. Grzegorza Rosy OMI. Najpierw ukazał swoją pracę budowniczego w Kamerunie Północnym. Zanalizował miejscowe powołania na braci zakonnych, ze szczególnym uwzględnieniem zdobywanego przez nich zawodu: mechanika, rolnika, pielęgniarza. Zaakcentował, że miejscem zdobywania umiejętności zawodowych i wykształcenia jest dla kandydatów na braci zgromadzenie zakonne (Rosa 2012, 54).

W kolejnym roku wydawniczym jedno $\mathrm{z}$ wydań periodyku zostało zadedykowane powołaniu i pracy braci zakonnych na misjach. Opracowanie Marcina Serwina OMI prezentuje braci oblatów z Madagaskaru. Autor przedstawił ich pracę jako: mechaników, budowlańców, duszpasterzy i rolników, a także ich powołanie. Krzysztof Zielenda OMI opisał zajęcia zmarłego w Kamerunie Północnym br. Stanisława Tomkiewicza OMI. Był pionierem misji oblackich i ich budowniczym. Charakteryzował się rozmodleniem i głęboką duchowością. Marcin Wrzos OMI natomiast prezentował prace br. Sebastiana Jankowskiego OMI, który prowadzi kuchnię dla ludzi ulicy w Kijowie. Wicepostulator Wiesław Olszewski OMI zaprezentował czytelnikom po raz kolejny postać br. Antoniego Kowalczyka OMI. Zwracał uwagę na jego głęboką duchowość, rozmodlenie, pobożność maryjną, a także pracowitość. Wskazywał na jego wkład w formację miejscowej ludności (Szymczycha 16-19; Serwin 20-21; Zielenda 32-33; Olszewski 36-37; Wrzos 34-35).

W kolejnym roczniku nie zamieszczono opracowań dotyczących braci oblatów na misjach.

W 2015 r. opisano działalność braci zakonnych na rzecz ludzi chorych. Na przykładzie werbisty lekarza Jerzego Kuźmy wskazywano, że to jeden z elementów realizacji ich powołania (Kuźma 23-24). 
Na łamach „Misyjnych Dróg” zauważalne są przeobrażenia w posłudze misyjnej braci zakonnych. W pierwszym etapie wydawania oblackiego periodyku (lata 1983-1994) przedstawiano wcześniejsze i współczesne misje z uwzględnieniem posługi braci zakonnych. W artykułach opisywano realizację powołania misyjnego braci polegającą przede wszystkim na wspieraniu księży działalności misjonarzy przez prace budowlane, mechaniczne, techniczne czy prowadzenie żeglugi. Prace duszpasterskie były nadzwyczajnym rodzajem posługi inicjowanym przez samych braci, wtórnym w stosunku do pierwotnego zajęcia. W drugim etapie wydawania „Misyjnych Dróg” (lata 1995-2011) w opublikowanych tekstach jako podstawowe zadanie podejmowane przez braci prezentowano posługi techniczne, mające na celu zabezpieczanie prac prowadzonych przez misjonarzy - księży. Zauważono komplementarność powołań księży i braci misjonarzy. Ukazano prowadzenie bezpośredniej ewangelizacji jako drugoplanowy, ale ważny element realizacji powołaniowej braci, podejmowany przede wszystkim $\mathrm{z}$ ich inicjatywy. W trzecim etapie działalności (lata 2012-2015), ale także pod koniec poprzedniego, zauważalna jest zmiana. Ewangelizacja bezpośrednia jest jednym $z$ elementów posługi brata zakonnego, do której jest posłany przez przełożonych. Prowadzi katechezy, nabożeństwa, wprowadza kult Bożego miłosierdzia. Tworzenie zaplecza technicznego misjonarzy jest elementem ich pracy równoważnym z bezpośrednią ewangelizacją.

\author{
TRANSFORMATION OF THE MISSIONARY MINISTRY \\ OF THE POLISH OBLATE BROTHERS IN THE LIGHT OF THE ARTICLES \\ PUBLISHED IN THE PERIODICAL "MISYJNE DROGI"
}

\title{
ABSTRACT
}

The article analyzes the contents of the review "Misyjne Drogi", published by the Polish Missionary Oblates of Mary Immaculate, with special focus on the theme of Oblate Brothers and their participation in missionary works of the Congregation. The changing image of the ministry of brothers is described according to three periods: 1983-1994, 1995-2011, 2012-2015. The articles published during the first period spoke mostly about brothers performing auxiliary tasks of farmer, construction worker, nurse etc. As the years passed, the authors have focused more on the direct participation of Oblate brothers in the ministry of evangelisation, on equal terms with Oblate priests.

Keywords: lay brother; oblates; mission; missionary magazine; "Misyjne Drogi"

Słowa kluczowe: bracia zakonni; oblaci; misje; czasopisma misyjne; „Misyjne Drogi” 


\section{BIBLIOGRAFIA}

Chrószcz, Alojzy. 2010. „Poświecenie nowej katedry w Yokadouma w Kamerunie.” Misyjne Drogi 28.6: 18-21.

Dąbrowski, Michał. 1984a. „Pięćdziesiąt lat wśród Indian i Eskimosów.” Misyjne Drogi 2.1: 28-36.

Dąbrowski, Michał. 1984b. „Misje na Północy dzisiaj.” Misyjne Drogi 2.1: 44

Dąbrowski, Michał. 1985. „Papież oddał całe swoje serce ludowi kanadyjskiemu.” Misyjne Drogi 3.2: 23.

Dąbrowski, Michał. 1987. „Gościliśmy u nas Księdza Prymasa.” Misyjne Drogi 5.3: 36-37.

Ferrara, Nicola. 1997. „Ożywiał go duch służby.” Misyjne Drogi 15.4: 13-15.

Głowacki, Leonard. 1984a. „Sekret bezrękiego brata - cz. 1.” Misyjne Drogi 2.1: 37-39.

Głowacki, Leonard. 1984b. „Sekret bezrękiego brata - cz. 2.” Misyjne Drogi 2.2: 54-58.

Głowacki, Leonard. 2007. „Szukając pracy, znalazł powołanie.” Misyjne Drogi 25.4: 34-36.

Guzik, Bogusław. 1994. „Nasza wspólnota seminaryjna.” Misyjne Drogi 12.4: 37-38.

Jankowicz, Stanisław. 2010. „Naszym życiem jest Ewangelia.” Misyjne Drogi 28.6: 34-37.

Kloch, Daniel. 1995. „Szkoła gospodarności.” Misyjne Drogi 13.4: 31.

Kloch, Daniel. 1998. „W prenowicjacie i nie tylko.” Misyjne Drogi 16.5: 26.

Kloch, Daniel. 2001. „Powstaje nowa wspólnota katolicka.”, Misyjne Drogi 19.5: 28.

Kloch, Daniel. 2008. „Trzeba zaufać Bożemu Miłosierdziu.” Misyjne Drogi 26.2: 33.

Kupka, Alfons. 1985. „57 lat w służbie misji.” Misyjne Drogi 3.4: 26-30.

Kupka, Alfons. 1989. „Brat Stanisław Wyryma.” Misyjne Drogi 7.1: 51.

Kurek, Antoni. 1984a. „Specjaliści od misji najtrudniejszych.” Misyjne Drogi 2.1: 14-21.

Kurek, Antoni. 1984b. „W płomieniach Cejlonu.” Misyjne Drogi 2.2: 20-25.

Kurek, Antoni. 1984c. „Oblacka misja w RPA.” Misyjne Drogi 2.3: 12-15.

Kuźma, Jerzy. 2015. „Brat ortopeda.” Misyjne Drogi 34.1: 23-24.

Lorenc, Mariusz. 1994. „Nasza budowa rośnie.” Misyjne Drogi 12.3: 36-37.

Lorenc, Mariusz. 1997a. „Wśród robotników leśnych” Misyjne Drogi 15.2: 26-27.

Lorenc, Mariusz. 1997b. „Moja pierwsza kaplica.” Misyjne Drogi 15.5: 30.

Olszewski, Mirosław. 2013. „Bezręki kowal.” Misyjne Drogi 32.5: 36-37.

Orzechowski, Tomasz. 2001. „Moja mała cząstka.”, Misyjne Drogi 19.5: 50.

Puchała, Waldemar. 1989. „Wśród plemienia Dogrib” Misyjne Drogi 7.2: 38.

Ramisy, Christian. i Wrzos, Marcin. 2009. „Jestem potrzebny jako brat zakonny.” Misyjne Drogi 27.3: 50 .

Rosa, Grzegorz. 1993. „Kościoły, kaplice, domy...” Misyjne Drogi 11.2: 39.

Rosa, Grzegorz. 1996. „Z północy na południe i z powrotem”, Misyjne Drogi 14.1: 27.

Rosa, Grzegorz. 2002. „Na chwałę Bożą i dla dobra braci.” Misyjne Drogi 20.4: 50.

Rosa, Grzegorz. 2011. „Grzegorz budowniczy.” Misyjne Drogi 30.4: 54.

Różański, Jarosław. 1991. „Montreal bramą do wielu narodów.” Misyjne Drogi 9.4: 18-19.

Sajewicz, Jan. 1989. „Tam ludzie stawali się lepsi, kędy my przeszli.” Misyjne Drogi 7.4: 52-54.

Serwin, Marcin. 2013. „Nie zasłaniają Jezusa.” Misyjne Drogi 32.5: 20-21.

Silva, Anzelm. i Quintus, Bernard. 1989. „Brat Stanisław Wyryma OMI.” Misyjne Drogi 7.2: 51.

Szymczycha, Kazimierz. 2013. „Nieodzowna pomoc.” Misyjne Drogi 32.5: 16-19.

Waas, Shivantha. 2004. „Pozdrawiamy serdecznie.” Misyjne Drogi 22.3: 13.

Wolnik, Zygmunt. 1993. „Przeżyliśmy kolejny cyklon.” Misyjne Drogi 11.3: 39.

Wolnik, Zygmunt. 1994. „Niespotykany cyklon.” Misyjne Drogi 12.3: 35-36.

Wrzos, Marcin. 2013. „Napromieniowany miłością.” Misyjne Drogi 32.5: 34-35.

Zapłata, Walenty. 1983. „Brat Stanisław.” Misyjne Drogi 1.3: 28-29.

Zielenda, Krzysztof. 2013. „Misjonarz, który nie głosił kazań.” Misyjne Drogi 32.5: 32-33.

Ziomek, Jacek. 2011. „Baba Simon czyli ojciec Simon.” Misyjne Drogi 29.2: 34-36.

Ziomek, Jacek. 2011. „Gdy lato trwa cały rok.” Misyjne Drogi 29.5: 28-29.

Ziomek, Jacek. 2010. „Po raz pierwszy stanąłem na ziemi kameruńskiej.” Misyjne Drogi 28.6: 28-29. 
Marcin Wrzos OMI, O. DR, ur. 1977 w Szubinie. Studia magisterskie z teologii (1998-2004) odbył w Wyższym Seminarium Duchownym Misjonarzy Oblatów w Obrze, afiliowanym do Wydziału Teologii Uniwersytetu im. Adama Mickiewicza w Poznaniu. Ukończył studia magisterskie z politologii oraz dziennikarstwa i komunikacji społecznej na Wydziale Nauk Politycznych i Dziennikarstwa UAM (2004-2007). W 2013 uzyskał doktorat z misjologii (Główne idee teologiczne polskiego czasopiśmiennictwa misyjnego po II wojnie światowej) na Wydziale Teologicznym Uniwersytetu Kardynała Stefana Wyszyńskiego w Warszawie. Aktualnie student polonistyki Uniwersytetu Jagiellońskiego w Krakowie oraz redaktor naczelny „Misyjnych Dróg”. Poszukiwania badawcze: misje w mediach, media na misjach. 


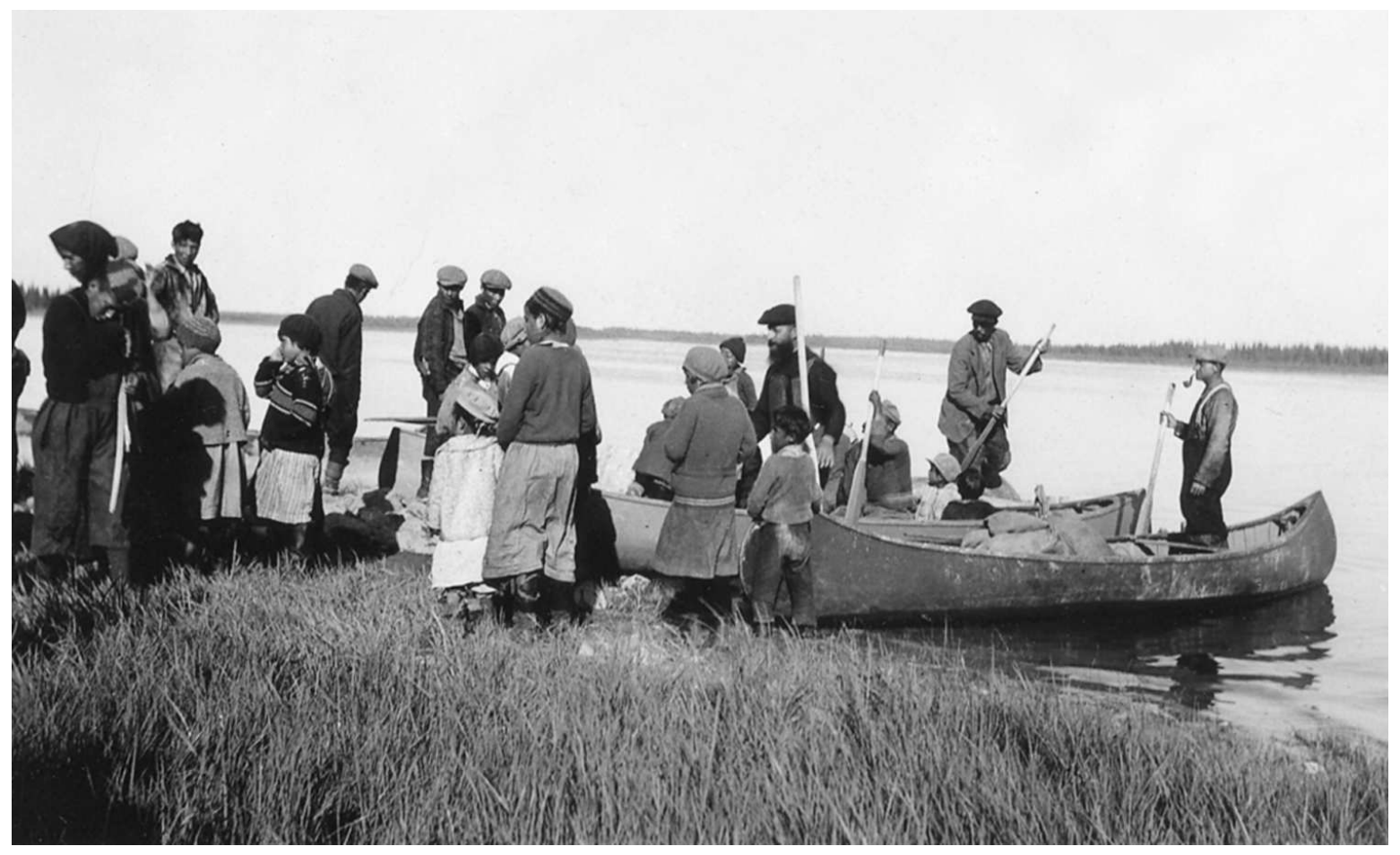

Vieux Comptoir - odwiedziny o. Couture OMI 


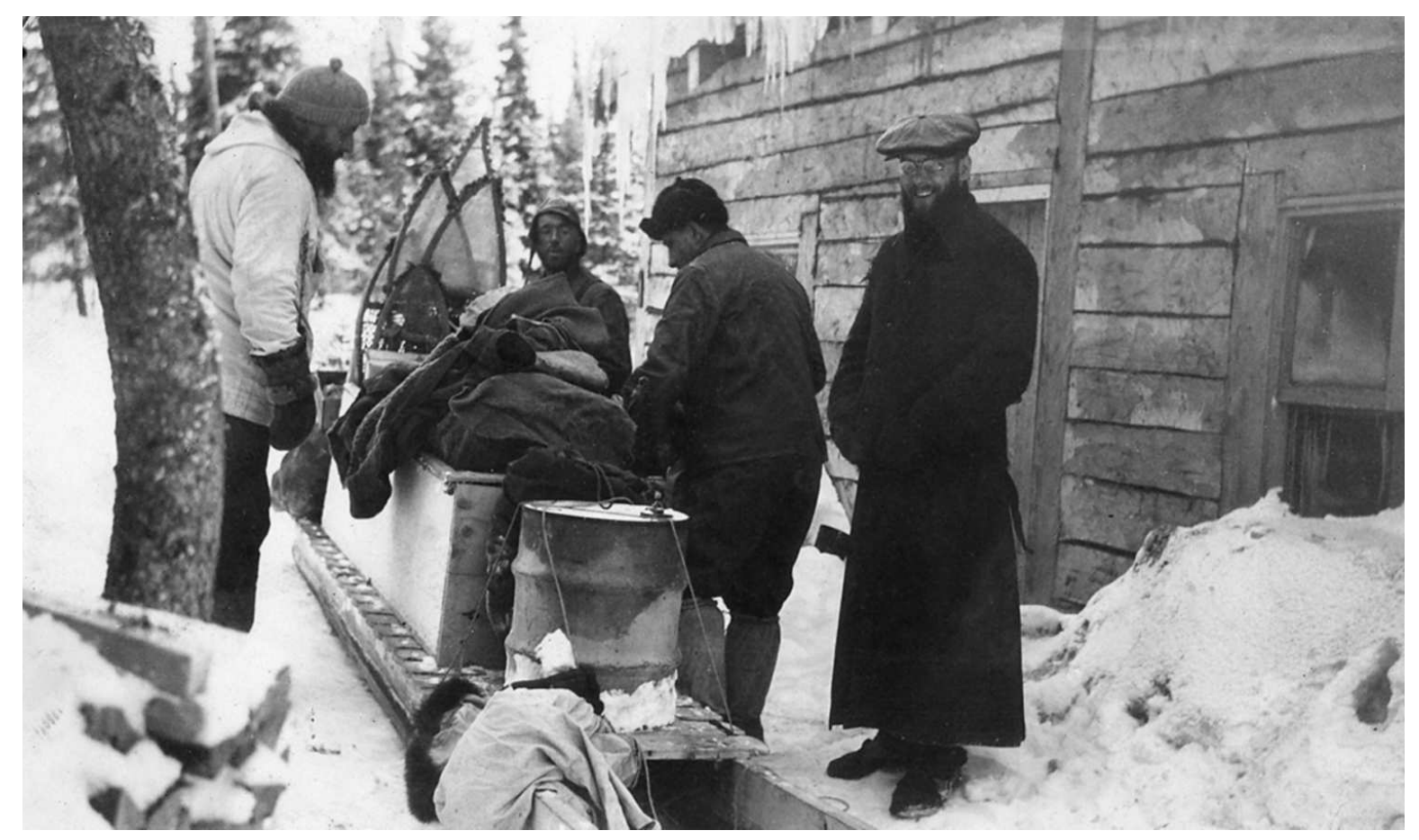

Vieux Comptoir - odwiedziny o. Couture OMI 